BIOTROPIA No. 20, 2003: 1-10

\title{
SYNERGISTIC ACTIVITY OF ENZYMES PRODUCED BY EUPENICILLIUM JAVANICUM AND ASPERGILLUS NIGER NRRL 337 ON PALM OIL FACTORY WASTES
}

\author{
TRESNAWATI PURWADARIA', NONI NIRWANA ${ }^{2}$, Pius P. KETAREN', DYAH ISWANTINI \\ PRADONO $^{2}$, and YANTYATI WIDYASTUTI ${ }^{3}$ \\ ' Research Institute for Animal Production, P. O. Box 221, Bogor 16002, Indonesia, \\ ${ }^{2}$ Department of Chemistry, Faculty of Science and Mathematics, Bogor Agricultural \\ University, Jl Raya Pajajaran Bogor, Indonesia, ${ }^{3}$ Research Centre for Biology-LIPI. \\ Jl. Juanda 18, Bogor 16002, Indonesia.
}

\begin{abstract}
The use of palm kernel cake (PKC) and palm oil mill effluent (POME), substances from palm oil factory wastes, for monogastric is limited by their high cellulose and mannan contents. Hydrolytic enzymes have been supplemented to increase the nutrient digestibility. The maximal digestibility was obtained in the synergistic action of all enzyme components including B-D-endoglucanase (CMCase), B-D-glucosidase, B-D-mannanase, p-D-mannosidase, and oc-Dgalactosidase. Two kinds of enzymes produced by Eupenicillium javanicum and Aspergillus niger NRRL 337 on the submerged culture containing 3\% coconut meal were selected to hydrolyze PKC or dry POME. Enzyme from E. javanicum contained higher CMCase, B-D-mannanase, and a-D-galactosidase activities, while that from A. niger NRRL 337 contained more p-D-glucosidase and p-D-mannosidase activities. Saccharification (hydrolytic) activities of enzyme mixtures on $\mathrm{PKC}$ and POME were determined at $\mathrm{pH} 5.0$, the optimal $\mathrm{pH}$ for $\mathrm{p}$-D-mannanase from E. javanicum, and at 5.4 the optimal $\mathrm{pH}$ for a-D-galactosidase from $E$. javanicum and P-D-glucosidase from $A$. niger NRRL 337. The enzyme proportions of E. javanicum and A. niger NRRL 337 were $100: 0,80: 20,60: 40,40: 60$, and $0: 100 \%$. The highest Saccharification activity on both substrates was observed on the mixture of $80 \%$ A. niger NRRL 337. The pH levels did not significantly affect Saccharification activity. Fiber components in PKC were more digestable than in POME. Further analysis on the reducing sugar components using thin layer chromatography showed that more monomers were produced in the 60 or $80 \%$ of $A$. niger NRRL 337. The glycosidases of A. niger NRRL 337 played more important role in the Saccharification activity.

Keywords: Synergistic activity/ palm kernel cake/palm oil mill effluent/ Eupenicillium javanicum/ Aspergillus niger NRRL 337

\section{INTRODUCTION}

Feeding costs account for $65-70 \%$ of the total cost of animal production. Therefore, it is important that most part of the feed can be utilized. Feeding of commercial chickens in Indonesia usually follows the formula applied in their original country (United States). Normally, the feed contains corn, soybean meal, and fishmeal. These feedstuffs are not abundant in Indonesia and have to be imported. On the other hand, rice bran, coconut meal, and palm oil factory wastes: palm kernel cake (PKC) and palm oil mill effluent (POME) are available. PKC is a residue of the oil extraction of palm fruit and constitutes up to $45 \%$ of palm oil bunches, while POME is the sludge of crude palm oil process and amounted to $2 \%$
\end{abstract}


of palm oil bunches. The fiber content of PKC exceeding 20\% could occur if shells and fruit fiber are not removed in the extraction process and over its half part is neutral detergent fiber (NDF) containing galactomannan and mannan (Swick and Tan 1995). The crude fiber (cellulose and lignin) of steamed PKC was 21.7\% (Supriyati et al. 1998). The cellulose, hemicellulose (galactomannan and mannan), and lignin of steamed POME were 17.3, 22.0, and 15.8\% (Purwadaria et al. 1998).

Supplementation of mannanase (galactomannanase) enzyme complex to improve the nutritional value is potential for improving feed quality. The components of the enzymes are pD-endoglucanase (CMCase), p-D-glucosidase, P-D-mannanase, P-D-mannosidase, and a-Dgalactosidase. Eupenicillium javanicum isolated from palm seed (Purwadaria et al. 1994) produced less P-D-glucosidase and more p-D-mannanase, P-D-mannosidase, and a-Dgalactosidase than Aspergillus niger NRRL 337 known as mannanolytic fungus (Araujo and Ward 1990; Haryati et al. 1997). The different activities of the enzyme component open up the possibilities of using the enzyme mixtures to improve the saccharification (hydrolysis) activity in PKC and POME. The synergistic effect using enzyme mixture of Trichoderma viride and A. ustus on alkali treated bagasse had been reported (Manonmani and Sreekantiah 1987). The saccharification on the substrate was $63 \%$ when using enzyme mixture of $1: 1$, while when individual enzymes were used 13.5 and 22.9\%, respectively. The information on optimal mixture of such enzyme composition will be useful in enzyme application for animal feeding.

The objective of the present study is to determine the synergistic activity of enzymes produced by E. javanicum and A. niger NRRL 337 to hydrolyze PKC and POME.

\section{MATERIALS AND METHODS}

\section{Palm kernel cake (PKC) and palm oil mill effluent (POME)}

PKC was obtained from palm oil factory by solvent extraction, while POME was obtained from the centrifugation of palm oil mill effluent. After centrifugation POME was dried under the sun. Both dry materials were ground to a fine powder $(0.5 \mathrm{~mm})$ using Wiley mill.

\section{Enzyme production}

Enzymes were produced by E. javanicum (RIAP collection) or A. niger NRRL 337 in the medium containing yeast extract $3 \mathrm{~g} / \mathrm{l}$, coconut meal $30 \mathrm{~g} / \mathrm{l}$ and minerals in $\mathrm{g} / 1\left(\mathrm{NH}_{4}\right)_{2} \mathrm{SO}_{4} 1.4$, $\mathrm{KH}_{2} \mathrm{PO}_{4}$ 2.0, $\mathrm{MgSO}_{4}$ 0.3, urea 0.3, and $\mathrm{CaCl}_{2} 0.3$ and in ppm $\mathrm{FeSO}_{4}$ 5, $\mathrm{MnSO}_{4} 16, \mathrm{ZnSO}_{4}$ 14, and $\mathrm{CoCl}_{2}$ 20. Molds were cultivated in $50 \mathrm{ml}$ medium in a $250 \mathrm{ml}$ flask at $29^{\circ} \mathrm{C}$ using reciprocal shaker (150 rpm), after inoculation with $2 \mathrm{ml}$ of spore suspension $\left(5 \times 10^{13}\right.$ and $30 \times 10^{13} / \mathrm{ml}$ for $E$. javanicum and A. niger, respectively) from five-day PDA culture slant. The 
Synergistic activity of enzymes on oil palm factory wastes - Tresnawati Purwadaria et al

incubation time for E. javanicum was five days, while that for A. niger was six days (Haryati et al. 1997). Sodium azide was added at $0.2 \%$ final concentration. The culture was then centrifuged (12000 rpm, $20 \mathrm{~min}, 4^{\circ} \mathrm{C}$ ) and supernatant was collected for enzyme assays and saccharification.

\section{Enzyme activities}

The activity of carboxymethylcellulase (CMCase) and $\beta$-D-mannanase were assayed by determining the reducing sugars produced from CMC and gum locust bean (mannan) as glucose or mannose, respectively (Haggett et al. 1979; Araujo and Ward 1990). One unit was defined as enzyme which liberates one p.mol glucose or mannose per minute. The glycosidase activities ( $\beta$-Dmannosidase, $\beta$-D-glucosidase, and $\alpha$-D-galactosidase) were assayed using nitrophenyl glycosides as substrates and one unit was defined as enzyme which liberates one umol nitrophenol per minute (Ide et al. 1983). Specific activity of all enzymes was calculated in unit/mg extracellular protein.

\section{Determination of protein and fiber component concentration}

Protein concentration was determined by Bradford method (1976) and Bovine serum Albumin was used as a standard. The concentrations of fiber components (cellulose, hemicellulose, lignin and silica) were calculated as neutral and acid dietary fiber according Van Soest and Robertson (1968).

\section{Determination of optimum $\mathrm{pH}$ and temperature}

The activities of both enzymes were determined at $50^{\circ} \mathrm{C}$ at different $\mathrm{pH}(4.6,5.0,5.4,5.8$, and 6.2) to obtain the optimum $\mathrm{pH}$, while for determination of the optimum temperature, the enzyme assays were carried out at maximum $\mathrm{pH}$ and different temperatures $(35,40,45,50,55$, and $60^{\circ} \mathrm{C}$ ).

\section{Saccharification activity towards PKC and dry POME}

Saccharification activities were determined following determination of avicelase (Haggett $e t$ al. 1979) using PKC and dry POME as substrates. The incubation time of the reaction was two hours and reducing sugars produced was determined with DNS method (Miller 1959). The activity value was expressed in unol glucose/ml liberated in one minute.

This reaction was also used to determine the synergistic activity of the enzyme mixtures. Several proportions of enzymes from E. javanicum and A. niger NRRL 337 (0:100, 20:80, 40:60, 80:20, and 100:0\%) were used. Aside from the concentration of reducing sugar produced in the reaction, the sugar components of the product were also determined using thin layer chromatography (Lestari et al. 2001). The samples and standards (glucose, cellobiose, mannose, mannobiose, and 
galactose) were spotted on plates of silica gel $60(20 \times 20 \mathrm{~cm})$. The reducing sugar concentrations of spots from samples were 3-8 ug, while the concentration of each standard was 8 ug. Elution was carried out using the mixture of ethanol, n-propanol and water (30:150:20). The elution was stopped when the solvent reached $2 \mathrm{~cm}$ from the top. The gel was then dried, and the elution was repeated to get better resolution. Spots were detected by spraying the plates by a mixture of aniline $(1 \mathrm{ml})$, diphenylamine $(1 \mathrm{~g}), 80 \% \mathrm{H}_{3} \mathrm{PO}_{4}(7.5 \mathrm{ml})$ in $50 \mathrm{ml}$ acetone and heated at $100^{\circ} \mathrm{C}$ for 1 hour.

\section{RESULTS AND DISCUSSION}

The activities of enzyme components (CMCase, ( $\beta$-D-mannanase, ( $\beta$-D-manno-sidase, $\beta$-Dglucosidase, and $\alpha$-D-galactosidase) involved in the fiber hydrolysis were determined (Table 1). The enzymes produced from E. javanicwn contained higher activities of CMCase, $\beta$-Dmannanase, and a-D-galactosidase, while those produced by $A$. niger contained higher $\beta$-Dmannosidase and P-D-glucosidase activities. It is already known that Aspergillus spp. produce more glycosidases (Ghose et al. 1985; Manonmani and Sreekantiah 1987; Haryati et al. 1997). The different major enzyme components of both enzymes suggested the possibility of combination between enzymes.

Table 1. Specific activities of CMCase, P-D-mannanase, P-D-mannosidase, p-D-glucosidase, and a-D-galactosidase of enzymes pr oduced by E. javanicum and A. niger NRRL 337 grown on coconut meal.

\begin{tabular}{lllllll}
\hline \multirow{5}{*}{ Molds } & \multicolumn{7}{c}{ Specific activities (U/mg) } \\
\cline { 2 - 7 } & $\begin{array}{l}\text { [Protein] } \\
(\mathrm{ug} / \mathrm{ml})\end{array}$ & CMCase & $\begin{array}{l}\mathrm{p}-\mathrm{D}-\mathrm{man} \\
\text { nanase }\end{array}$ & $\begin{array}{l}\text { P-D- } \\
\text { Gluco } \\
\text { sidase }\end{array}$ & $\begin{array}{l}\text { a-D- } \\
\text { galacto } \\
\text { sidase }\end{array}$ & $\begin{array}{l}\text { P-D- } \\
\text { manno } \\
\text { sidase }\end{array}$ \\
\hline E. javanicum & 435 & 18.6 & 1172.2 & 1.5 & 16.8 & 1.1 \\
A. niger NRRL 33' 498 & 9.9 & 14.1 & 3.1 & 2.3 & 3.3 \\
\hline
\end{tabular}

The optimal synergistic activity was obtained when the optimal $\mathrm{pH}$ and temperature conditions were applied. The optimal $\mathrm{pH}$ and temperature of E. javanicum $\beta$-D-mannanase and $\alpha$ $\mathrm{D}$-galactosidase were at 5.4 and $50^{\circ} \mathrm{C}$, and 5.0 and $55^{\circ} \mathrm{C}$ respectively, while those of $A$. niger $\beta$ $\mathrm{D}$-glucosidase were at 5.0 and $55^{\circ} \mathrm{C}$ (Figures 1 and 2). The temperature difference gave less effect than the $\mathrm{pH}$ difference. A temperature increase from 50 to $55^{\circ} \mathrm{C}$ reduced $\beta$-D-mannanase activity at $22.7 \%$, while the temperature reduction from 55 to $50^{\circ} \mathrm{C}$ reduced activities of $\alpha$-D- 
galactosidase and ( $\beta$-D-glucosidase at 11.3 and $10.9 \%$, respectively. An increase of $\mathrm{pH}$ from 5.0 to 5.4 increased $39.5 \%$ of the $\beta$-D-mannanase activity, and reduced 24.9 and $13.5 \% \alpha$-Dgalactosidase and $\beta$-D-glucosidase, respectively. Further analyses at these conditions were used to determine saccharification activity towards PKC and POME (Table 2).

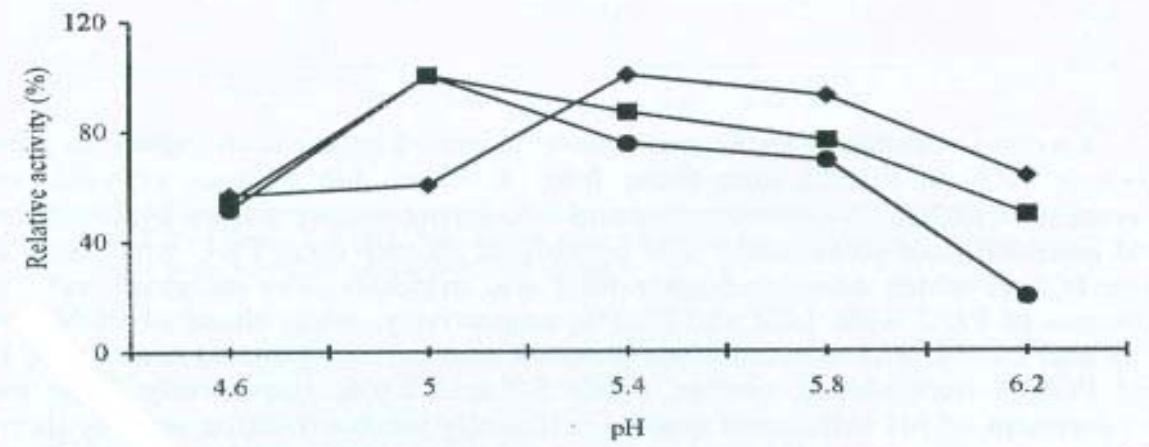

Figure 1. Optimum, for E. jovanicum $\alpha-\mathrm{D}$-galactosidase $(\bullet)$ and $\beta-D-m a n n a n a s e ~(\bullet)$, and $A$. niger $\beta$ D-glucusidas.

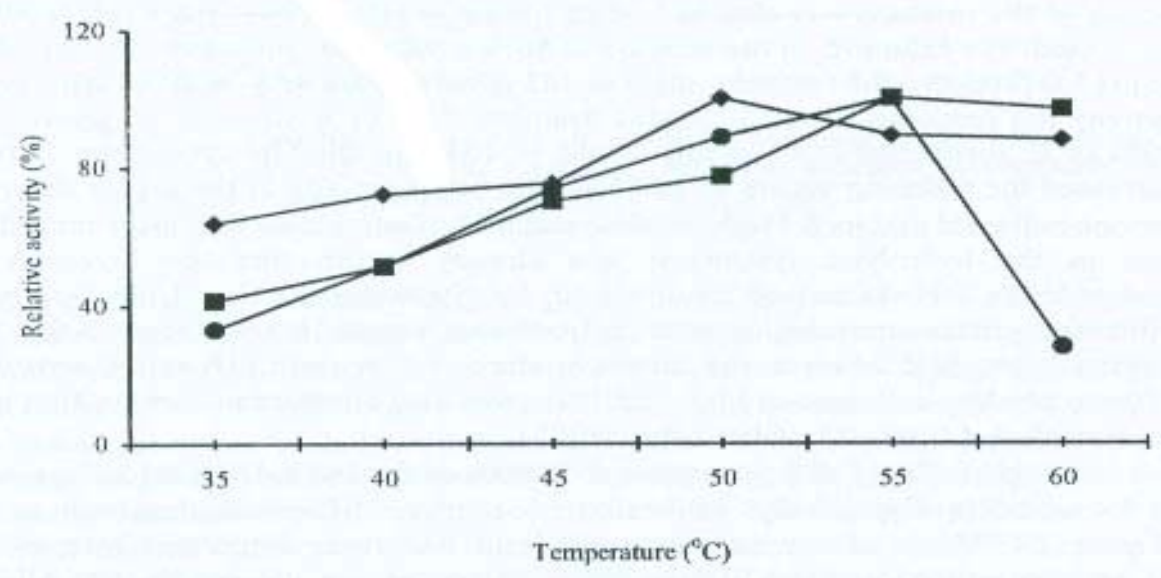

Figure 2. Optimum temperatures for $E$. javanicum a-D-galactosidase $(\bullet)$ and $\beta$-D-mannanase $(\bullet)$, and A. niger P-D-glucosidase ( $\mathbf{0}$ ). 
BIOTROPIA No. 20,2003

Table 2. Saccharification activity of enzymes produced by E. javanicum and A. niger NRRL 337 towards $\mathrm{PKC}$ and dry POME at various $\mathrm{pH}$ and temperatures.

\begin{tabular}{llccc}
\hline \multirow{2}{*}{ Molds } & \multirow{2}{*}{ Substrates } & \multicolumn{3}{c}{ Saccharification activity $(\mu \mathrm{mol} / \mathrm{ml})$} \\
\cline { 3 - 5 } & & $\mathrm{pH} 5.0: 50^{\circ} \mathrm{C}$ & $\mathrm{pH} 5.4: 50^{\circ} \mathrm{C}$ & $\mathrm{pH} 5.0: 55^{\circ} \mathrm{C}$ \\
\hline \multirow{2}{*}{ E. javanicum } & PKC & 11.11 & 13.70 & 12.50 \\
A. niger & POME & 0.44 & 0.56 & 0.55 \\
NRRL 337 & PKC & 1.90 & 0.55 & 1.48 \\
& POME & 0.29 & 0.33 & 0.43 \\
\hline
\end{tabular}

Enzymes produced by E. javanicum showed higher Saccharification activity towards PKC or POME than those from A. niger due to high activities of E. javanicum CMCase, $\beta$-Dmannanase and $\alpha$-D-galactosidase in hydrolyzing cellulose and hemicellulose compounds. The hydrolysis activity upon PKC was also higher than POME which contains higher fiber and minerals. The cellulose and lignin contents of PKC were 14.2 and $20.5 \%$, respectively, while those of POME were 20.8 and $25.6 \%$. The hemicellulose (mannan and galactomannan) contents of PKC and POME were almost similar, being 5.3 and 5.6\%, respectively. The microenvironment of $\mathrm{pH}$ influenced more significantly Saccharification activity than the temperature, therefore the synergism activities towards PKC and POME were carried out at $\mathrm{pH} 5.0$ and 5.4 which were the optimum $\mathrm{pH}$ for glycosidases and $\beta$-D-mannanase, respectively. Both $\mathrm{pH}$ conditions were applied at $50^{\circ} \mathrm{C}$.

All mixtures of enzymes at $\mathrm{pH} 5.0$ or 5.4 showed the synergistic Saccharification either towards PKC or POME (Figures 3 and 4). The highest synergistic action of the mixture was obtained when higher volumes of $A$. niger ( 60 or $80 \%$ ) were used. For example, in the mixture of $80 \%$ A. niger the hydrolysis upon POME at $\mathrm{pH} 5.0$ produced the reducing sugar at $162 \mathrm{uj} / \mathrm{ml}$ (Figure 4A). Without synergistic activity the reducing sugars produced from the $80 \%$ of $A$. niger $(86.4 \mathrm{uj} / \mathrm{ml})$ and $20 \%$ of $E$. javanicum $(17.8 \mathrm{uj} / \mathrm{ml})$ would be $104.2 \mathrm{uj} / \mathrm{ml}$. The synergistic activity increased the reducing sugars up to $55 \%$. The better activity in the higher $A$. niger rations indicated that its $\beta$-D-glucosidase and $\beta$-D-mannosidase play more important role in the hydrolysis system. It was already known that the digestion of disaccharides (cellobiose and mannobiose) by glycosidases reduced the feed back inhibition effects on endoglucanase and endomannanase. It was reported that the highest synergistic action in the culture mixture of T. reesei D-16 and A. went// Pt 2804 to produce cellulase and hemicellulase was also observed at composition of 1 ( $T$. reesei): 4 (A. wentii) (Ghoseetal. 1985).

The optimum $\mathrm{pH}$ of E. javanicum $\beta$-D-mannanase and $\alpha$-D-galactosidase were at 5.4 and 5.0, respectively, while that of $A$. niger $\beta$-D-glucosidase was at 5.0 (Figure 1). Which of the enzyme component had more important role in the synergistic activity was not clearly indicated by varying $\mathrm{pH}$ conditions. All $\mathrm{pH}$ conditions and substrates produced similar pattern and showed the highest synergistic activity at 60 or $80 \%$ A. niger application. Moreover, considering the reducing 


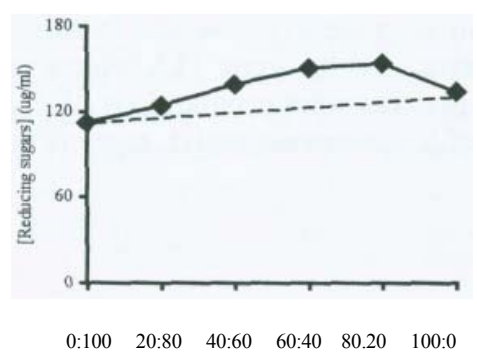

A. niger : E. javanicum (\%)

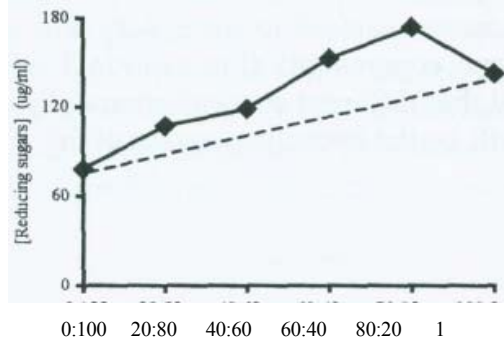

A. niger : E. javanicum (\%)

Figure3. Synergistic saccharification towards PKC by enzyme mixtures of A. niger and E. javanicum at pH 5.0 (A) and 5.4 (B). The dotted lines represent the theoretical reducing sugar values expected for a non-synergistic saccharification.

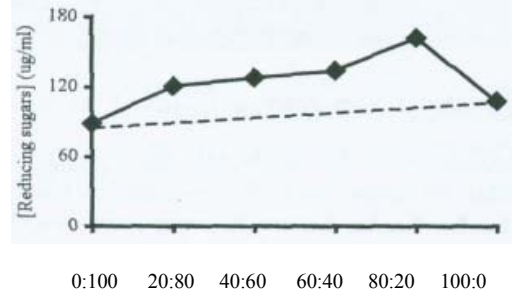

A. niger : E. javanicum (\%)

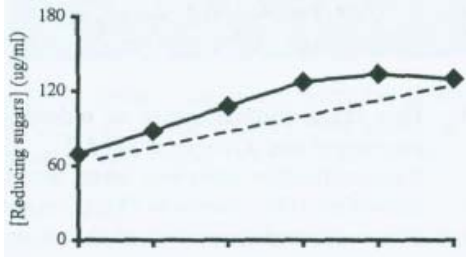

0:100 20:80 40:60 60:40 80:20 $\quad$ 100:0 A. niger : E. javanicum (\%)

Fiaure4. Syncrmstic saccharification towards POME by enzyme mixtures of A. niger and E. javanicum at $\mathrm{pH} \sim 5.0$ (A) and 5.4 (B). The dotted lines represent the theoretical reducing sugar values expected for a non-synergistic saccharification.

sugar produced by PKC and POME at $\mathrm{pH} 5.4$ by $100 \%$ A. niger $(143 \mathrm{jg} / \mathrm{ml}$ and $130 \mathrm{uj} / \mathrm{ml}$, respectively) was higher than that of $100 \%$ E. javanicum $(78 \mathrm{uj} / \mathrm{ml}$ and $69 \mathrm{fg} / \mathrm{ml}$, respectively), then the proportion of $A$. niger should be higher than $80 \%$ on PKC and $60 \%$ on POME (Figures 3 and 4). Although the optimum $\mathrm{pH}$ of $A$. niger B-D-glucosidase was at 5.0, only saccharification upon POME showed a better synergy at $\mathrm{pH}$ 5.0, while that upon PKC was better at $\mathrm{pH}$ 5.4. The obtained result might be due to the high mineral concentration in POME that influenced the activity of each enzyme component differently. The ash and silica contents of PKC were 8.5 and $1.7 \%$, respectively, while those of POME were 17.6 and $9.5 \%$. The high mineral or cation contents in POME might have influenced the buffering capacity of the substrate and affected the $\mathrm{pH}$ in the reaction. 
The role of every enzyme component in the synergistic action ws difficult to be detected since all enzyme components took part in the reaction. Detailed successive reaction in the synergistic action had been clearly observed in the pure enzyme components (Purwadaria 1995). However, results from TLC plates indicated that different concentrations of sugar components were produced on PKC and POME by the hydrolysis action of the mixtures of E. javanictan and A, niger (Figure 5).
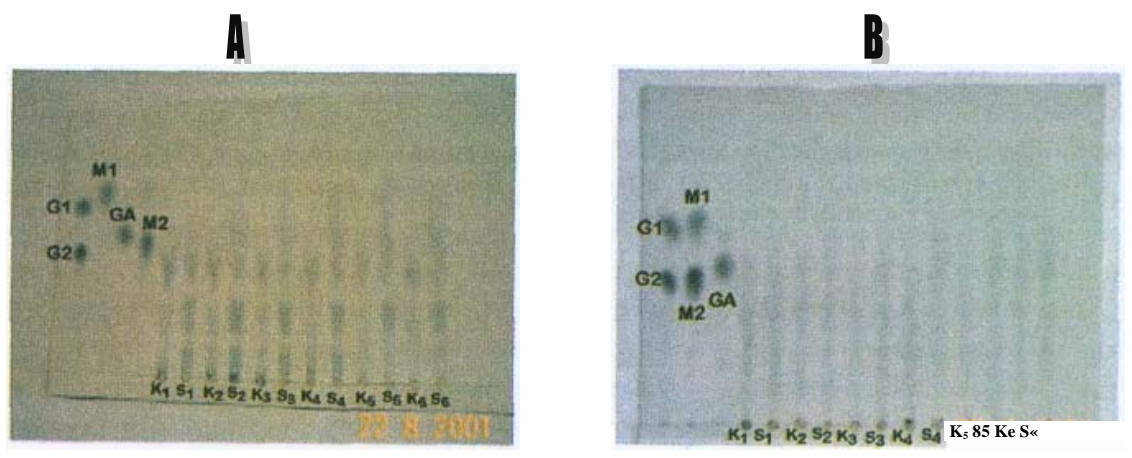

Figure 5. Thin layer chromatogram of reducing sugars produced from synergistic sachanfication of $E$. javanicum and $A$. niger at $\mathrm{pH}$ 5.0.

Saccharification activities were determined towards PKC (A) and POME (B). Glucose (Gi), cellobiose (Gi), mannose (Mi), mannobiose $\left(\mathrm{M}_{2}\right)$, and galactose (GA) were used as reference. The concentration of each standard was $8 \%$. KI, $\mathrm{Kj}, \mathrm{K}_{3}, \mathrm{Kj}, \mathrm{K}_{5}$, and $\mathrm{K}$, were controls without incubation, while $\mathrm{Si}, \mathrm{S}_{2}, \mathrm{~S}_{3}, \mathrm{~S}_{4}, \mathrm{~S}_{5}$, and $\mathrm{S}_{6}$ were samples from the composition of $A$. niger : E. javanicum at 0:100, 20:80,40:60, 60:40, 80:20, and 100:0\%.

The chromatogram of PKC digestion was clearer than that of POME due to its higher mineral content which had disturbed the separation (Figure 5). The reducing sugars of controls produced from the mixture of enzymes and substrate without incubation were compared with samples from the mixture of enzymes and substrate with incubation. Smaller amounts of reducing sugars were detected from the controls (substrates) compared to the samples. Oligosaccharides (trimers and more) resulted from endoglucanase or endomannanase activities especially by higher composition of E. javanicum in the incubated samples (Figure 5A-S], 82, and 83) were much more than those of controls. The oligosaccharides produced were further digested by glycosidases of E. javanicum and the addition of glycosidases from A. niger (Figure 5A and B). Addition of 60 or $80 \% A$. niger to the enzyme mixtures produced more monomers and dimers including mannose, glucose, galactose, and cellobiose.

The possibility of higher hydrolysis activity resulted from synergistic action will contribute a beneficial effect in the enzyme application on monogastric. The 
Synergistic activity of enzymes on oil palm factory wastes trtsnawati Purwadaria tl at,

incorporation of carbohydratases known as inducer enzymes is inhibited by the feed soluble sugar content prepared for energy source. The addition of glycosidases produced by A. niger ( $\beta-\mathrm{D}-$ glucosidase and $\beta$-D-mannosidase) on top of $\alpha$-D-galactosidase from E.javanicum might have increased the digestion of the dimmers such as cellobiose and mannobiose that reduced the inhibition effect of the dimmers (short olygosaccharides) on endoglucanase and endomannanase. Therefore, the application of enzyme cocktails in animal di»ts is considered to be more appropriate than single enzyme.

\section{REFERENCES}

Araujo, A. \& , O. P. Ward. 1990. Extracellular mannanases and ;.alactanases from selected fungi. J. Ind. Microbiol. 6:171178.

Bradford, MM. 1976. A rapid and sensitive method for the quantitation of microgram quantities of protein utilizing the principle of protein-dye binding. Anal. Biochem. 72: 248-254.

Ghose, T.K., T Panda, and V. S, Bissau. 1985. Effect if culture phasing and mannanase on production of cellulose and hemicellulase by mixed culture ot Trichoderma reesei D 1-6 and Aspergillus wendtii Pt 2804. Biotechnol. Bioeng. 25: $1353-1361$.

Haggett, K.D., P.P. Gray and N.W Dunn. 1979. Crystalline cellulose degradation by a strain of Cellulomonas and its mutants derivatives. Eur. J. Appl. Microb. Biotechnol. 8: 183-190.

Haryati, T, T. Purwadaria, J. Darma, and B. Tangendjaja, 1997. Production of extracellular glycosidase by Eupenicillium javanicum and Aspergillus niger NRRL 337 on the coconut meal substrate. Proc. Second Conf. on Agricultural Biotechnology, Jakarta, Indonesia, 13-15 Juni 1995.AARD, Indonesia, p. 517-522

Ide, J.A., J. M. Daly, and P.A.D. Rickard. 1983. Production of glycosidase activity by Cellulomonas during growth on various carbohydrate substrate. Eur. J. Appl. Microb. Biotechnol. 18: 100-102.

Lestari, P., A. A. Danvis, K. Syamsu, N. Richana, and D.S. Damardjati. 2001. Analisis gula reduksi hasil hidrolisis enzimatik ubi kayu oleh a-amylase termostabil dari Bacillus stearothermophilus Til 12 (Reducing sugar analyses on the enzymatic hydrolytic product of cassava by thermostabil a-amylase from Bacillus stearothermophilus Til 12). J. Mikrobiol. Indon. 6: 23-26.

Manonmani, H.K. and K.R. Sreekantiah. 1987. Saccharification of sugar cane bagasse with enzymes from Aspergillus ustus and Trichoderma vinde. Enzyme Microb. Technol. 9: 484-488.

Miller, G.L. 1959. Use of dinitrosalicylic acid reagent for determination of reducing sugar. Anal. Chem. 31:426-428.

Purwadaria, T. 1995. Synergism in the hydrolysis of cellulose by Endoglucanase I and II (Endo 1 and II) and cellobiohydrolase (CBH I) purified from Cellulomonas CS1-17. Annalcs Boaoricnses. 3: 12-24.

Purwadaria, T., A.P. Sinurat, T. Haryati, I. Sutikno, Supriyati and J. Darma. 1998. Korelasi antara aktivitas enzim mananase dan selulase terhadap kadar serat lumpur sawit hasil fermentasi dengan Aspergillus niger (The correlation between mannanase and cellulose activities towards fibre content of palm oil sludge fermented with Aspergillus niger). JTTV 3: 230-236.

Purwadaria. T., T. Haryati, and J. Darma. 1994. Isolasi dan seleksi kapang mesofilik penghasil mananase (Isolation and selection of mesophylic molds producing mannanases). Ilmu \& Peternakan 7(2): 26-29. 
BIOTROPIA No. 20,2003

Supriyati, T. Pasaribu, H. Hamid, and A.P. Sinurat. 1998. Fermentasi bungkil inti sawit secara substrat padat dengan menggunakan Aspergillus niger (Solid substrate fermentation of palm kernel cake using Aspergillus niger). JITV 3: $165-170$.

Swick, R.A. and P.H. Tan. 1995. Considerations in using common Asian protein meals. Tech. Bull. ASA MITA(P) No. 083/12/94. Vol. Po25

Van Soest, P.J. and J.B. Robertson. 1968. System of analysis for evaluating fibrous feeds. In W.J. Pigden ed. Standardization of analytical methodology for feed. Cent. Canada, IDRC. 134e. 